\title{
The terrestrial invertebrate fauna of Edgeøya, Svalbard: Arctic landscape community composition reflects biogeography patterns
}

\author{
M. L. Ávila-Jiménez ${ }^{1,2,3} \cdot$ T. Solhøy $^{2} \cdot$ D. J. Gwiazdowicz $\cdot$ A. Fjellberg ${ }^{5} \cdot$ K. Dózsa-Farkas ${ }^{6} \cdot$ F. Monson ${ }^{7}$. \\ W. H. De Smet ${ }^{8} \cdot$ E. Stur ${ }^{9} \cdot$ T. Ekrem $^{9}$. S. J. Coulson ${ }^{1,10}$
}

Received: 14 April 2018 / Revised: 8 February 2019 / Accepted: 16 February 2019 / Published online: 27 March 2019

(C) The Author(s) 2019

\begin{abstract}
Colonisation and immigration history is often neglected as a factor when investigating community or species distribution patterns. However, for dynamic systems that are still reacting to large-scale environmental change, such as the retreat of the ice since the last glacial maximum, colonisation history may explain a large amount of the variation between geographically distinct communities. The High Arctic archipelago of Svalbard presents an opportunity to test whether it is possible to observe the effects of large-scale biogeographical patterns on species distribution at landscape scales. Svalbard has one of the best described inventories of the invertebrate fauna in the Arctic. Nonetheless, the majority of the species records originate from the more accessible west coast and the invertebrate fauna of the whole eastern region, including Edgeøya, is virtually unknown. Edgeøya is located at the eastern fringe of the archipelago on the boundary between Palaearctic and Nearctic faunas. It was expected that post-colonisation dispersal within Edgeøya would conceal routes to the archipelago. Samples were obtained from six locations along the coast of Edgeøya between 2009 and 2010. 140 invertebrate species were identified belonging to 69 different genera of which 16 are new records for Svalbard. Most new species present an eastern Palaearctic distribution. Habitat variables (percentage cover of moss, lichen, vascular plant, or bare soil) fail to explain $35.5 \%$ of the differences among sites. However, cluster analysis reveals a clear east-west distribution pattern across the island suggesting that pan-Arctic dispersal routes can be identified even at relatively short geographical scales.
\end{abstract}

Keywords Invertebrates $\cdot$ Diversity $\cdot$ Landscape ecology $\cdot$ Polar $\cdot$ Dispersal

\section{Introduction}

Deceased: T. Solhøy.

Electronic supplementary material The online version of this article (https://doi.org/10.1007/s00300-019-02471-x) contains supplementary material, which is available to authorized users.

M. L. Ávila-Jiménez

mlavilaj@gmail.com

1 Department of Arctic Biology, University Centre in Svalbard, P.O. Box 156, 9170 Longyearbyen, Norway

2 Ecological and Environmental Change Research Group (EECRG), Department of Biology, University of Bergen, p.b. 7800, 5200 Bergen, Norway

3 Present Address: Northumberland College, College Road, Ashington NE63 9RG, UK

4 Department of Forest Pathology, University of Life Sciences, Wojska Polskiego 71c, 60-625 Poznan, Poland

5 Tjøme, Norway
Biogeographical patterns are most likely the result of the interaction among different geographical, environmental and historical factors (Thompson and Townsend 2006). Large biogeographical scenarios are considered in

6 Department of Systematic Zoology and Ecology, Biological Institute of the Eötvös, Loránd University- ELTE, Pázmány Péter sétány 1/C. H-1117, Budapest, Hungary

7 National Museums Liverpool, Liverpool L3 8EN, UK

8 ECOBE Department of Biology, University of Antwerp, Campus Drie Eiken, Universiteitsplein 1, 2610 Wilrijk, Belgium

9 Department of Natural History, NTNU University Museum, 7491 Trondheim, Norway

10 ArtDatabanken, The Swedish Species Information Centre, Swedish University of Agricultural Sciences, Box 7007, 75007 Uppsala, Sweden 
ecology as a framework to study macro-ecological patterns, whereby historical factors (e.g. post-glacial colonisation) are used to understand large scale temporal and spatial variations. Even though niche processes can influence large-scale species distributions patterns (Keith et al. 2012), it remains unclear whether these processes are identifiable at smaller scales and, consequently, whether historical factors must be taken into account when analysing ecological processes at short scale.

This dual-theory scenario seems to dominate Arctic ecology and patterns of glacial refugia and dispersal routes have been identified as the main factors shaping High Arctic plant distribution (Alsos et al. 2007; Eidesen et al. 2013). A pan-Arctic study showed that collembolan communities reflect largely northward colonisation routes following the ice retreat after the Last Glacial Maximum (LGM, ca. 10,000 years before present) (Ávila-Jiménez et al. 2011). Nonetheless, fine-scale species distribution continues to be defined based on environmental factors (Ávila-Jiménez et al. 2011) and it remains unclear whether recent colonisation history can influence community assemblages, and thus, whether this should be accounted for in ecological studies.

The archipelago of Svalbard lies in the European High Arctic to the north of Norway. The invertebrate fauna of this island group is amongst the most studied in the Arctic, possibly representing the most complete invertebrate inventory in the Arctic (Hodkinson 2013). Amongst the earliest scientific reports of the terrestrial invertebrates of Svalbard are the papers of Boheman (1865) and Holmgren (1869). Summerhayes and Elton $(1923,1928)$ expanded the knowledge of these communities but the majority of publications have been produced during the last 50 years. While the climate is typically High Arctic with characteristic low annual air temperatures, over 1000 species of terrestrial or freshwater invertebrate have been recorded in the archipelago, including over 800 species of Tardigrada, Arachnida, Collembola, Insecta, and Crustacea (Coulson and Refseth 2004; Coulson et al. 2014a) Yet, these reports are mainly based on studies from the western parts of the principal island, Spitsbergen, and only scattered studies are to date available from elsewhere in the archipelago (Coulson et al. 2014a).

Edgeøya is the third largest island in the archipelago and forms the main land area in the South East Svalbard nature reserve, an area expected to become an Arctic environmental reference region (Norwegian White Paper 22, 2008-2009). Nonetheless, knowledge on how, or why, to conserve this area is based largely on vegetation surveys and there have been few reports concerning the terrestrial invertebrate fauna of the island with the exceptions of descriptions of the occurrence of testate amoebae (Beyens et al. 1986), Tardigrada (Maucci 1996; Zawierucha et al. 2013), and diatoms (Beyens and De Bock 1989).
Despite its complex glacial history (Ingólfsson and Landvik 2013), it is generally accepted that the current invertebrate fauna of Svalbard in general, and Edgeøya in particular, assembled following the main ice retreat after LGM (Coulson et al. 2014a). This follows the general dispersal patterns to Svalbard described for plant species and inferred for invertebrates (Alsos et al. 2007; Ávila-Jiménez et al. 2011; Eidesen et al. 2013). Based on collembolan communities, Svalbard has been described to consist of three distinct biogeographical units: a north Atlantic unit, a Holarctic unit, and a third unit shared with the area to the east of the Ural Mountains up to the Beringian strait and stretching over the ice-free Siberian extension during the LGM (ÁvilaJiménez and Coulson 2011). The link between the eastern Palaearctic regions has been repeatedly associated with the Siberian branch of the transpolar drift as dispersal route to the eastern coastline of Svalbard (Alsos et al. 2007; ÁvilaJiménez et al. 2011). Svalbard hence represents a key location on the boundary between the Palaearctic and Nearctic faunas (Ávila-Jiménez et al. 2011; Coulson et al. 2014a), with Edgeøya located at the eastern end of the boundary. Thus, this archipelago is directly influenced from the west through dispersal routes following main Atlantic air and water currents, and from the east mainly following the Siberian branch of the transpolar drift (Haugan 1999; Johansen 1999; Alsos et al. 2007; Ávila-Jiménez et al. 2011), where sea ice pressure over winter can potentially push driftwood well above the tide line.

The influence of dispersal routes can be comparatively inferred by analysing diversity data from Svalbard against distribution data from other Arctic locations; however, whether these influences can be identified at the community level at the landscape scale, and therefore, whether relatively small-scale studies are relevant to infer larger biogeographical patterns, remains unclear. Hence to understand the ecology and colonisation history of Svalbard studies from the eastern regions such as Edgeøya are required to complement the knowledge of the western coasts.

Here, we test whether large-scale biogeographical patterns can be observed at the short landscape scale (few $\mathrm{km}$ ). To this end, we analysed biodiversity and distribution patterns of selected groups of invertebrates from different terrestrial locations within the island of Edgeøya. Several species not previously recorded from Svalbard were collected and which display a predominantly Palaearctic distribution. With the exception of the Rotifera and Araneae (these groups were not collected from the west coast due to logistical difficulties), our results showed a clear east-to-west distribution pattern, suggesting that main pan-Arctic dispersal routes can be identified even at the landscape level. Consequently, main dispersal routes and colonisation history must be taken into account when using community composition as an ecological parameter even at relatively geographic short scales. 


\section{Materials and methods}

\section{Local environment and glacial history}

Svalbard is a remote archipelago in the European High Arctic approximately $800 \mathrm{~km}$ from the Norwegian mainland and $600 \mathrm{~km}$ from Greenland (Fig. 1a). The island of Edgeøya comprises an area of c. $500 \mathrm{~km}^{2}$ (Norwegian Polar Institute 2003) and lies in the east of the Svalbard archipelago at $77.8^{\circ} \mathrm{N} 22.6^{\circ} \mathrm{E}$ (Fig. 1a). The island consists of a wide flat central plateau at an altitude of 250-350 m.a.s.l. with mountain peaks attaining altitudes of 450 to $500 \mathrm{~m}$ (Fig. 1b) and is bisected east-west and north-south by a complex valley system. The vegetation of the plateau region is predominantly highest poppy fellmark while the valley floors, lying some $300 \mathrm{~m}$ below the plateau, are characterised by moss tundra vegetation (Zonneveld et al. 2004). Permanent ice covers approximately $40 \%$ of the island with ice covered the mountain summits and a large glaciated region lying along the south eastern coast.

Svalbard has a typical High Arctic climate. Annual mean air temperature is $-3.5{ }^{\circ} \mathrm{C}$ (1981-2010) (Førland et al. 2011) while summer mean air temperature is $+5.2^{\circ}$ dropping down to $-11.7^{\circ} \mathrm{C}$ in winter (Førland et al. 2011). Soil surface temperatures, the overwintering habitat of the majority of the soil fauna, typically decline below $0{ }^{\circ} \mathrm{C}$ in September and remain frozen until thawing the subsequent June. During this period, soil surface temperatures can dip to below $-30^{\circ} \mathrm{C}$ in locations without an insulating snow cover but are often in the range of -5 to $-15{ }^{\circ} \mathrm{C}$ (Convey et al. 2015, 2018). Precipitation is low, with only $190 \mathrm{~mm}$ per year recorded at the airport in Longyearbyen (Norsk Meteorologiskinstitutt, eKlima.no), the principal settlement, the majority of which is snow. Warmer temperate waters and winds from the North Atlantic Drift arrive at Svalbard from the south-west and elevate temperatures along the western coastal margins (indicated by the arrows in Fig. 1a). With its eastern margins influenced by the cold northerly Arctic ocean currents, temperatures on Edgeøya tend to be slightly colder than locations at similar latitudes on the west coast of Spitsbergen and present short summers with air temperatures typically positive from mid-May until late September (Fig. 2) (Przybylak et al. 2014).

During the LGM, the Weichselian episode, the islands were largely covered by the Svalbard-Barents Sea ice sheet until approximately 10,000 years ago when the ice started to retreat (Landvik et al. 1998). A recent reassessment of the ice dynamics in the Svalbard region suggests that the ice caps were far less static than previously believed and that areas of ice-free land were present in Svalbard throughout the LGM (Ingólfsson and Landvik 2013). Nonetheless, these ice-free areas were ephemeral and none of them persisted throughout the entire glacial period. Even if ice-free areas could have persisted in the north west of the archipelago there is little suggestion that plant species have survived the LGM in situ during this period (Brochmann et al. 2003) (but see Westergaard et al. 2011) and there is no evidence of invertebrate refugia. Hence, current communities are
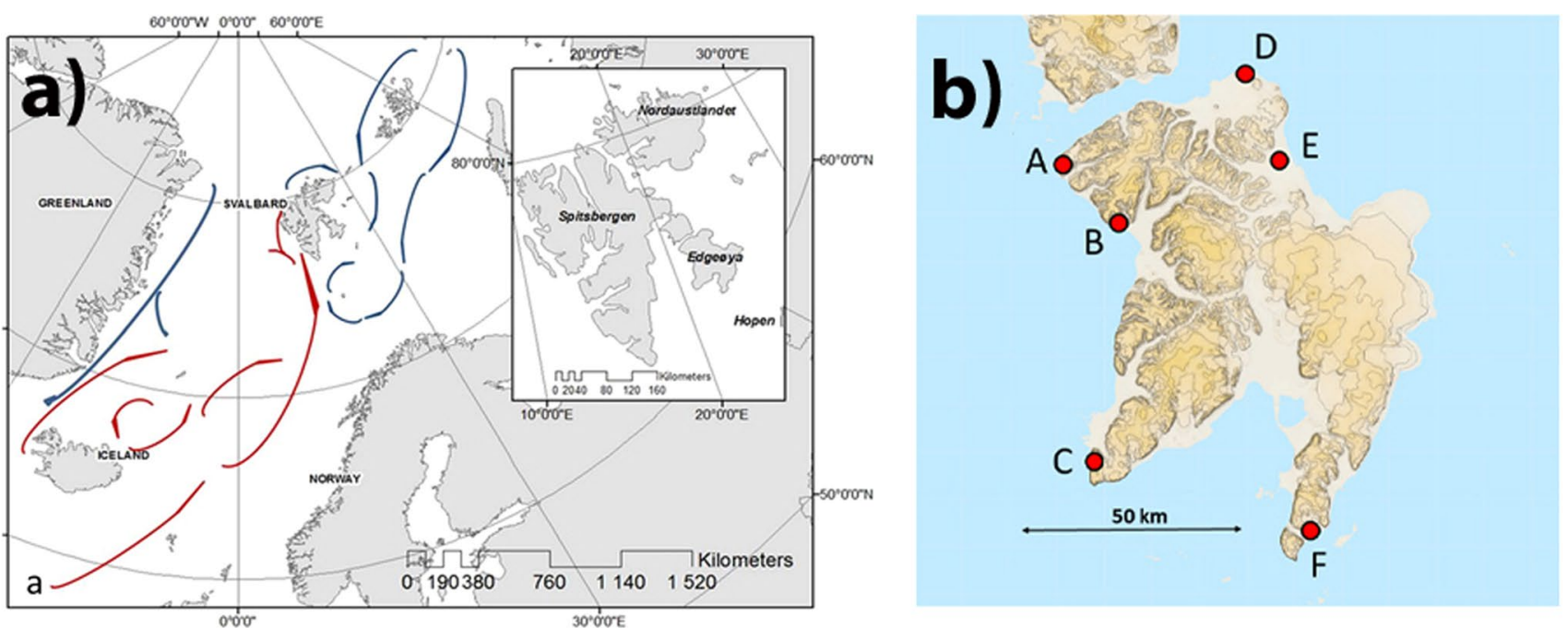

Fig. 1 a) Location of Svalbard. a Location of Svalbard archipelago in the Arctic ocean. Arrows indicate the direction of principal ocean currents (red warm Atlantic water, blue polar cold currents). Inset: main islands of the Svalbard archipelago and location of Edgeøya. b The island of Edgeøya with the locations of sites sampled in 2009 (a, b) and 2010 (d-f) indicated. (A): Kapp Lee; $(B)$ : Diskobukta; $(C)$ : Russebukta; $(D)$ : Kapp Heuglin; $(E)$ : Blåbukta; $(F)$ : Negerdalen. $100 \mathrm{~m}$ contour lines presented. Scale bar $=50 \mathrm{~km}$. Map source TopoSvalbard, Norwegian Polar Institute 


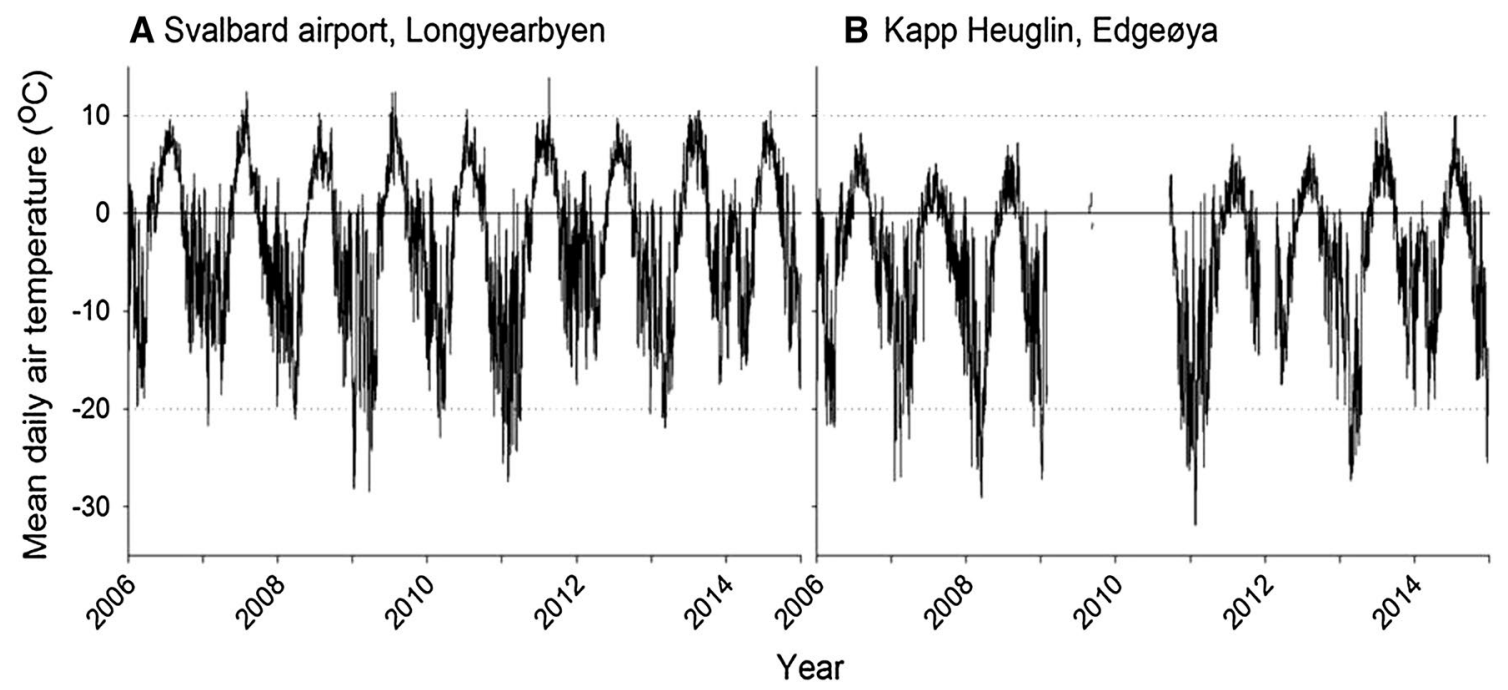

Fig. 2 Main daily air temperature from east and west locations. a Main daily air temperature measured at Svalbard airport, Longyearbyen. b Main daily air temperature measured at Kapp Heuglin, northeast of Edgeøya. Reference lines indicate $+10{ }^{\circ} \mathrm{C}$ and $-20{ }^{\circ} \mathrm{C}$ (dotted

thought to have assembled subsequent to the retreat of the ice and during the last 10,000 years.

\section{Sampling sites}

The six sampling sites were selected to represent the range of terrestrial habitats characteristic of the island, including polar semi-desert, mesic habitat, and moss-dominated wet habitats (Fig. 3; Table 1). Soil samples were collected on July 14, 2009 from three localities on the west coast of Edgeøya: Kapp Lee, Diskobukta and Russebukta (Fig. 3a-c). The remaining three locations, Blåbukta, Kapp Heuglin and Negerdalen (Fig. 3d-f), were sampled on July 15, 2010. At each site 15 samples were collected. Each sample was approximately $10 * 10 \mathrm{~cm}$ (approximate wet weight $0.1-0.4 \mathrm{~kg}$ )' core' taken though the vegetation, litter, and upper soil layer. These samples were placed into self-seal plastic bags for transport back to the University Centre in Svalbard in Longyearben for extraction.

\section{Invertebrate extraction and identification}

Microarthropods were placed into Tullgren funnels (Burkard Scientific Ltd., Uxbridge, U.K.) at the University Centre in Svalbard (UNIS) in Longyearbyen within $24 \mathrm{~h}$ of sampling and extracted into $96 \%$ ethanol until the soil was completely dry.

For the Enchytraeidae, two samples from each site were maintained at $5{ }^{\circ} \mathrm{C}$ before shipping to Eötvös Loránd University, Budapest, Hungary where Enchytraeidae specimens were wet extracted in Baermann funnels (O'Connor 1962) lines) and $0{ }^{\circ} \mathrm{C}$ (solid line). Data source: Norwegian Meteorological Institute, www.Eklima.no (accessed on the 16 August 2015). Data for 2010 is not available

and subsequently identified. Enchytraeids were first observed and measured alive and subsequently fixed in $70 \%$ ethanol. Some of the fixed specimens were stained with borax-carmine and then passed through an ethanol dehydration series (from $70 \%$ to absolute), mounted temporarily in clove oil and then permanently in Euparal between two coverslips. Hence the worms were observable from both sides. All the important morphological characters were recorded in vivo, drawn and photographed. The whole-mounted specimens were re-examined and photographed as well.

To facilitate identification, mesostigmatic mites were mounted on permanent (Hoyer's medium) and semi-permanent (lactic acid) slides and identified using the latest taxonomical literature (Gwiazdowicz et al. 2011a, b; Kolodochka and Gwiazdowicz 2014; Teodorowicz et al. 2014). Collembola and oribatid mites were identified to species by morphological taxonomic techniques following (Fjellberg 1998, 2007) (Collembola) and (Norton and Behan-Pelletier 2009) and (Schatz and Fischer 2011) (Oribatida).

Chironomidae (Diptera) larvae were dissected and tissue samples of all morphotypes from all localities (total $n=39$ ) were submitted to the Canadian Centre for DNA Barcoding (CCDB) as part of the Norwegian Barcode of Life project (NorBOL). Barcoding, based on the partial sequencing of the cytochrome c oxidase subunit 1 (COI) gene, is commonly used to identify immature life stages of holometabolous insects (Stur and Ekrem 2011) by comparing their genetic sequences against a reference library. In our case, we could match larval DNA barcodes with those of adults identified by ourselves. Even in cases when a match is not found in the reference library, DNA barcodes do still provide 


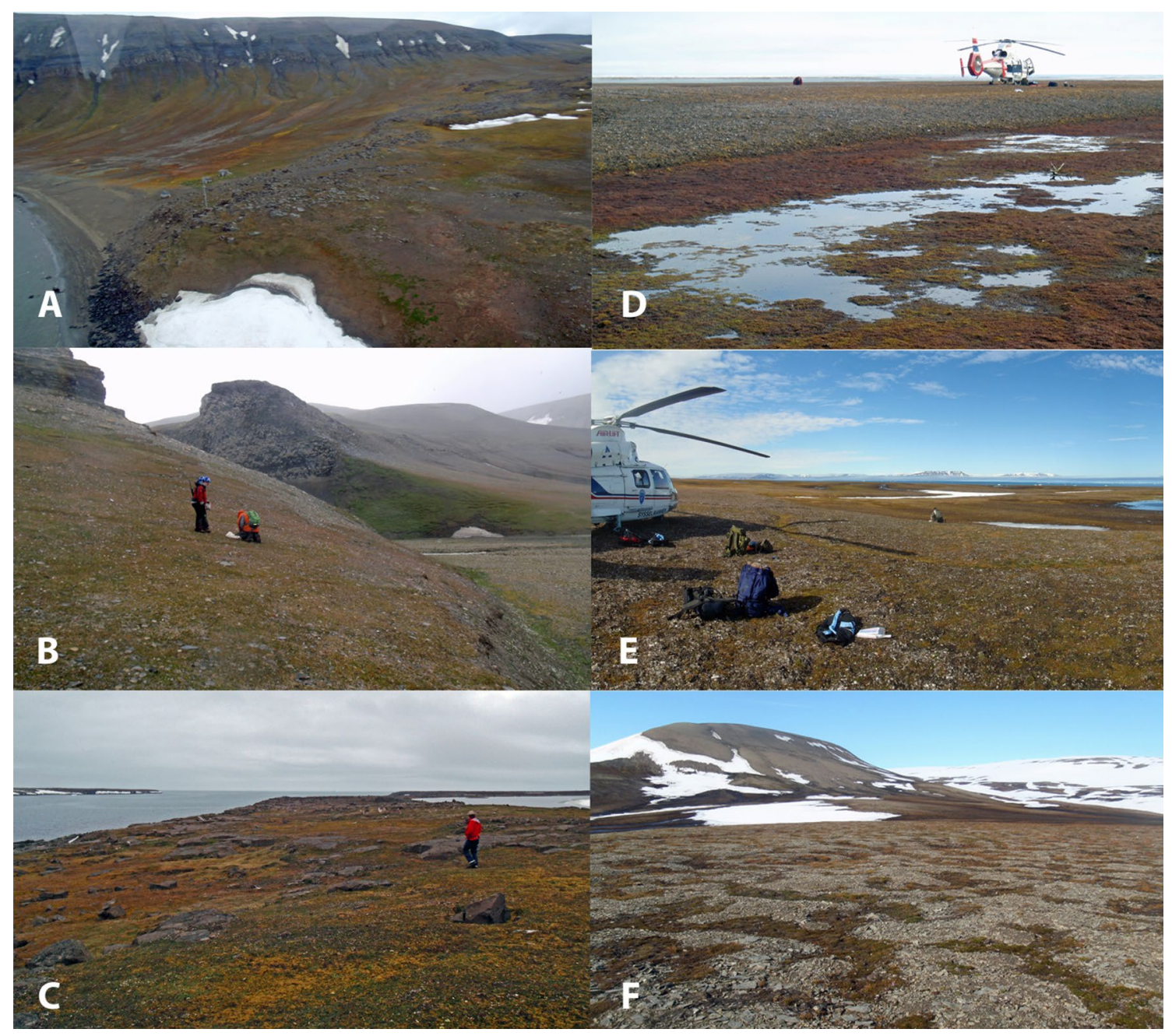

Fig. 3 Sampling locations on Edgeøya; a Kapp Lee, b Diskobukta, c Russebukta, d Kapp Heuglen, e Blåbukta, f Negerdalen. Images are illustrative of individual sampling locations but various habitat types were sampled at each location. See Table 1 for site descriptions

important molecular diagnostic characters useful to separate the unidentified immature specimen from other known taxa in the barcode reference database. DNA was extracted following standard protocols at CCDB (Ivanova et al. 2006) and the $648 \mathrm{bp}$ barcode fragment of the COI gene was amplified using the primer sets LCO1490/HCO2198 (Folmer et al. 1994) or the cocktail C_LepFolF/C_LepFolR (HernándezTriana et al. 2014). Subsequently, the PCR products were subjected to bi-directional Sanger sequencing. DNA barcodes, metadata for all vouchers and GenBank accession numbers are available from the dataset DS-CHEDGE in the Barcode of Life Data Systems (BOLD, www.boldsystem s.org, dx.doi.org/10.5883/DS-CHEDGE). Selected specimens were macerated in $10 \% \mathrm{KOH}$ and slide mounted in Euparal for morphological confirmation. Adult chironomids in the barcode reference library were identified using the relevant taxonomic literature (Sæther 1975, 1990, 1995, 2004; Ferrington and Sæther 2011).
For the study of rotifers, mosses were allowed to air-dry and shipped to Antwerp University, Belgium, where subsamples of each moss were rehydrated in a Petri dish by adding distilled water; after $1 \mathrm{~h}$. animals were sorted from the samples and examined using a Leitz Orthoplan microscope. Scanning electron microscopy of the rotifer trophi was performed with a Philips 515 operated at $20 \mathrm{kV}$, after dissolving tissues in dilute $\mathrm{NaOCl}$ (De Smet 1998). The major works used for the identification of bdelloids are Donner (1965) and Kutikova (2005), and for monogononts Koste (1978), Segers (1995) and De Smet and Pourriot (1998). The taxonomy and nomenclature of the rotifers follows Jersabek et al. (2015).

\section{Sample storage and data availability}

The identified material is deposited at Poznan University of Life Sciences, Department of Forest Pathology, Wojska 
Table 1 Site descriptions (based on Zonneveld et al. 2004)

\begin{tabular}{|c|c|c|c|c|c|c|c|}
\hline \multirow[t]{2}{*}{ Location } & \multirow[t]{2}{*}{ Coordinates } & \multirow[t]{2}{*}{ Landscape } & \multirow[t]{2}{*}{ Soils } & \multirow[t]{2}{*}{ Vegetation community } & \multicolumn{3}{|c|}{ Cover $(\%)$} \\
\hline & & & & & Lichen & Mosses & Herbs \\
\hline Kapp Heuglin & $\begin{array}{l}\text { N78 } 8^{\circ} 14^{\prime} 45 \\
\text { E } 022^{\circ} 48^{\prime} 21\end{array}$ & Terraced moss tundra & $\begin{array}{l}\text { Slightly gravelly clay loam } \\
\text { to loam }\end{array}$ & Tomentypnum, Luzula & 90 & 80 & 15 \\
\hline Blåbukta & $\begin{array}{l}\mathrm{N} 78^{\circ} 03^{\prime} 27 \\
\mathrm{E} 022^{\circ} 52^{\prime} 53\end{array}$ & Terraced moss tundra & $\begin{array}{l}\text { Slightly gravelly clay loam } \\
\text { to loam }\end{array}$ & Tomentypnum, Luzula & 90 & 80 & 15 \\
\hline \multirow[t]{3}{*}{ Negerdalen } & $\begin{array}{l}\mathrm{N} 77^{\circ} 17^{\prime} 42 \\
\mathrm{E} 022^{\circ} 53^{\prime} 36\end{array}$ & Coastal moss tundra & Silty clay to sandy loam & Eriophorum, Carex & 95 & 85 & 15 \\
\hline & & Complex of gravelly & $\begin{array}{l}\text { Stoney loams and stoney } \\
\text { sands }\end{array}$ & $\begin{array}{l}\text { Tomentypnum, Saxifraga, } \\
\text { Oxyria, Papaver }\end{array}$ & 40 & 30 & 15 \\
\hline & & Open poppy fjellmark & $\begin{array}{l}\text { Silt to stones. Some finer } \\
\text { material }\end{array}$ & $\begin{array}{l}\text { Barren community of Papa- } \\
\text { ver, Saxifraga }\end{array}$ & 20 & 15 & $<5$ \\
\hline Russebukta & $\begin{array}{l}\mathrm{N} 77^{\circ} 32^{\prime} 18 \\
\mathrm{E} 20^{\circ} 50^{\prime} 44\end{array}$ & Coastal moss tundra & Silty clay to sandy loam & $\begin{array}{l}\text { Eriophorum, Carex, Tomen- } \\
\text { typnum }\end{array}$ & 95 & 85 & 15 \\
\hline Diskobukta & $\begin{array}{l}\mathrm{N} 77^{\circ} 58^{\prime} 15 \\
\mathrm{E} 21^{\circ} 19^{\prime} 05\end{array}$ & Terraced moss tundra & $\begin{array}{l}\text { Silt to stones. Some finer } \\
\text { material }\end{array}$ & Tomentypnum, Luzula & 20 & 15 & $<5$ \\
\hline \multirow[t]{2}{*}{ Kapp Lee } & $\begin{array}{l}\mathrm{N} 78^{\circ} 4^{\prime} 47 \\
\mathrm{E} 20^{\circ} 49^{\prime} 27\end{array}$ & Valley floor moss tundra & Silty clay/sandy clay loam & $\begin{array}{l}\text { Eriophorum, Carex, Saxi- } \\
\text { fraga, Tomentypnum }\end{array}$ & $75-90$ & $60-70$ & $15-25$ \\
\hline & & Mossy/poppy fjellmark & $\begin{array}{l}\text { Gravelly to very gravelly } \\
\text { clays and loams }\end{array}$ & Papaver/Cardamine & 45 & 40 & 5 \\
\hline
\end{tabular}

Polskiego 71, PL-60-625 Poznan, Poland (Mesostigamata) and the Department of Arctic Biology, University Centre in Svalbard, P.O. Box 156, NO-9171, Longyearbyen, Svalbard, Norway (Collembola, Mesostigmata and Oribatida). Chironomidae are deposited at NTNU University Museum, Norwegian University of Science and Technology, NO-7491 Trondheim, Norway. Enchytraeidae are deposited at the Department of Systematic Zoology and Ecology of the Eötvös Loránd University Pázmány Péter sétány 1/C, H-1117, Budapest, Hungary, Rotifer material is deposited at ECOBE, Department of Biology, University of Antwerp, B-2610 Wilrijk, Belgium.

\section{Environmental variables}

Habitat descriptions were collected in situ and detailed in Table 1 . In addition, the total cover of mosses, lichens and herbs were quantified in situ and used to estimate the influence of habitat type on invertebrate distributions. Detailed temperature records from different parts of the island are not available, but only expected to differ significantly at very small scales. The 15 samples taken from each site were collected on a variety of aspects and vegetation types to cover as much micro-variability as possible in temperature patterns.

\section{Statistical analysis}

Species number $(\mathrm{S})$ and Shannon Diversity Index $(\mathrm{H})$ were calculated from presence/absence data using the algorithms included in the R package vegan (Oksanen et al. 2007). The presence of geographical differences in species distribution were assessed only for those groups for which data were available from all the sampling sites (Online Resource 1) using hierarchical clustering based on Bray Curtis dissimilarities and presence/absence data using R (R Development Team 2014). The number of meaningful clusters was identified using a screeplot built using the basics algorithms included in R. The clustering observed can be explained by habitat characteristics using canonical correspondence analysis including species presence/absence data and habitat description data (Table 1) in the R package MASS (Venables and Ripley 2013). Comparisons between collembolan assemblages from the different parts of Edgeøya and other High Arctic islands was undertaken using hierarchical clustering based on Bray Curtis dissimilarities and presence/ absence data. Collembolan distribution from other Arctic islands was extracted from Babenko and Fjellberg (2006). Canonical correspondence analysis was conducted to assess the influence of habitat variability on the observed distribution of collembolan.

\section{Results}

\section{Overall distribution data}

A total of 140 invertebrate species from 69 different genera (Online Resource 1), including Rotifera, Enchytraeidae, Mesostigmata, Oribatida, Araneae, Collembola and Insecta were identified. Of these, 16 were new records to Svalbard 
(four Rotifera, three Enchytraeidae, two Mesostigmata, two Collembola, and five Diptera) (Table 2). Differences among sites in the number of species and Shannon's diversity index are shown in Fig. 4. Shannon Species Diversity Index was approximately constant across all sampling sites, although the number of species found in the west coast nearly doubled that of the east coast (Fig. 4). Figure 5a highlights the differences in species distribution among sites based on Bray Curtis dissimilarities including a canonical correspondence analysis biplot showing sites and habitat variables. According to the canonical correspondence analysis, up to $35.5 \%$ of the variability observed is not accounted by environmental variables.

\section{Rotifera}

A total of 32 Rotifera species (27 Bdelloidea and 5 Monogononta) were collected from the easternmost sites of Edgeøya. These sites presented similar number of species (20, 13 and 20 for Kapp Heuglin, Blåbukta and Negerdalen, respectively) and Shannon's Diversity Index (2.9, 2.5 and 2.9 for Kapp Heuglin, Blåbukta and Negerdalen, respectively). Habrotrocha solida Donner, 1949, Macrotrachela quadricornifera vanoyei Schepens, 1954, Pleuretra humerosa (Murray, 1905), and Encentrum sp. nov. are new records for Svalbard (Table 2), whereas the others are already reported from other regions of the archipelago (Online Resource 1).

Table 2 New species records for Svalbard

\begin{tabular}{|c|c|c|c|c|c|c|c|}
\hline & \multirow[t]{2}{*}{ Species } & \multicolumn{6}{|c|}{ Distribution } \\
\hline & & KL & DK & $\mathrm{RS}$ & KH & BL & NG \\
\hline \multicolumn{8}{|l|}{ Rotifera } \\
\hline \multirow[t]{3}{*}{ Bdelloidea } & Habrotrocha solida Donner, 1949 & NA & NA & NA & - & - & $*$ \\
\hline & Macrotrachela quadricornifera vanoyei Schepens, 1954 & NA & NA & NA & * & - & - \\
\hline & Pleuretra humerosa (Murray, 1905) & NA & NA & NA & $*$ & - & - \\
\hline Monogononta & Encentrum sp. nova & NA & NA & NA & * & - & - \\
\hline \multirow[t]{3}{*}{ Enchytraeidae } & Cernosvitoviella cf. pusilla Nurminen, 1973 & - & - & $*$ & - & - & - \\
\hline & Mesenchytraeus melanocephalus Christensen \& Dózsa- Farkas, 1999 & - & - & - & * & * & $*$ \\
\hline & Mesenchytraeus sp.nov. & $*$ & - & $*$ & * & * & - \\
\hline \multicolumn{8}{|l|}{ Acari } \\
\hline \multirow[t]{2}{*}{ Mesostigmata } & Neoseiulus ellesmerei (Chant \& Hansell, 1971) & - & - & $*$ & - & - & - \\
\hline & Saprosecans baloghi Karg, 1964 & - & $*$ & - & - & - & - \\
\hline \multirow[t]{2}{*}{ Collembola } & Folsomia ciliata Babenko \& Bulavintsev, 1993 & $*$ & * & - & - & - & - \\
\hline & Pseudanurophorus psammophilus (Potapov \& Stebaeva, 2002) & $*$ & * & - & - & - & - \\
\hline \multicolumn{8}{|l|}{ Diptera } \\
\hline \multirow[t]{5}{*}{ Chironomidae } & Allocladius sp. 1ES & - & * & $*$ & - & - & - \\
\hline & Metriocnemus sp. 1ES & - & $*$ & $*$ & $*$ & - & - \\
\hline & Smittia longicosta (Edwards, 1922) & $*$ & $*$ & - & - & - & - \\
\hline & Smittia sp. 6ES & - & $*$ & - & - & - & - \\
\hline & Smittia sp. 28ES & - & - & - & - & - & $*$ \\
\hline
\end{tabular}

$K L$ Kapp Lee, $D K$ Diskobukta, $R S$ Russebukta, $K H$ Kapp Heuglin, $B L$ Blåbukta, $N G$ Negerdalen, $N A$ not assessed

*Present, -absent

Fig. 4 Invertebrate diversity per site. Number of species described per site (left) and $\mathrm{H}$ diversity index (right). KL: Kapp Lee, DK: Diskobukta, RS: Russebukta, KH: Kapp Heuglin, BL: Blåbukta, NG: Negerdalen
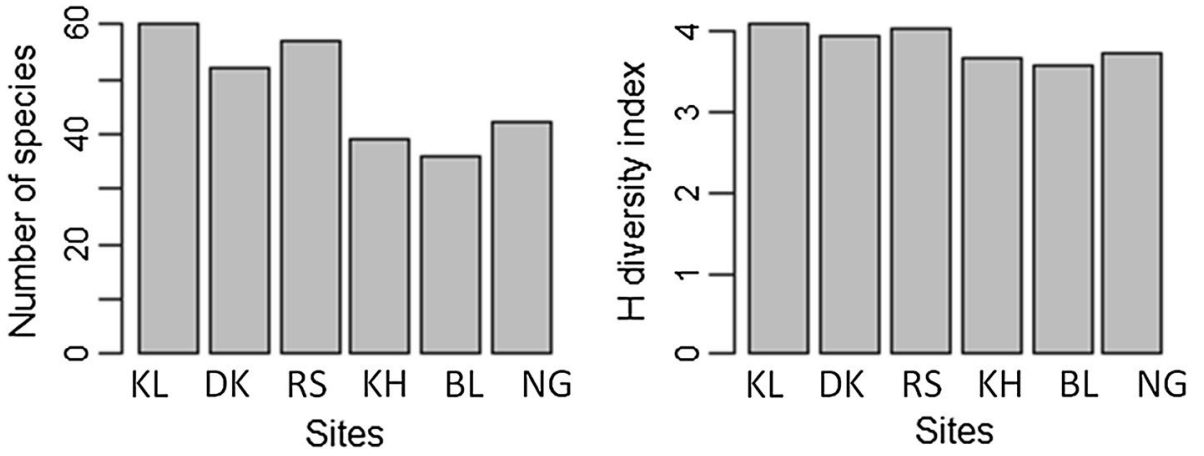
Fig. 5 Similarities among sites. a Cluster dendrogram based on Bray Curtis dissimilarity and presence/absence data. Eastern and western clusters highlighted in red. b Canonical correspondence analysis byplot including habitat variables and species distribution per site. 1: Rusebukta and Blåbukta; 2: Kapp Lee and Diskobukta. c Screeplot showing an inflexion point between cluster 2 and the following clusters. d Cluster dendrogram including collembolan assemblages from all High Arctic islands. Green boxes indicate western Edgeøya locations while blue arrows indicate eastern locations. $K L$ Kapp Lee, $D K$ Diskobukta, $R S$ Russebukta, $K H$ Kapp Heuglin, $B L$ Blåbukta, $N G$ Negerdalen. (a): Svalbard, (b): Franz Joseph Land, $(c)$ : Novaya Zemlya, $(d)$ : Severnaya Zemlya, $(e)$ : New Siberian Islands, $(f)$ : Wrangel Island, $(h)$ : Queen Elisabeth Islands

\section{Enchytraeidae}

Out of the 12 Enchytraeidae species (belonging to six different genera) recorded from both the west and the east coast of Edgeøya, three were new to Svalbard, Mesenchytraeus melanocephalus Christensen \& Dózsa- Farkas, 1999, Cernosvitoviella cf. pusilla Nurminen, 1973, and Mesenchytraeus sp.nov. (Table 2, Online Resource 1). The sampling sites were quite homogeneous, 4 of the 11 species occurring at all size sampling locations. Similarly, the two coast communities were akin with only $C$. cf. pusilla, Russebukta, on the west coast, being restricted to one coast.

\section{Acari}

From the 33 species of mites found (Online Resource 1), 12 belonged to the Mesostigmata, including the new records to Svalbard Neoseiulus ellesmerei (Chant \& Hansell, 1971) and Saprosecans baloghi Karg, 1964 found only on the west coast of Edgeøya. The remaining species were Oribatida. None of the oribatid mite species were new records to Svalbard. The Acari displayed greater species diversity on the west coast than the east coast. Eleven species of Mesostigmata were collected from the west coast of which five were restricted to these west coast sites, while only seven species were observed on the east coast. Only one species, Arctoseius multidentatus Evans, 1955, was collected from all sampling sites and only one species, Arctoseius tschernovi Makarova, 2000, was restricted to the east coast.

The Oribatidae displayed a similar pattern to the Mesostigmata. Only one species (Diapterobates notatus (Thorell, 1871)) was collected from all six sampling locations and of the eighteen species identified, 12 were seen on the west coast (three only on this coast) and nine at the east coast sites (six only from the east coast sites) (Online Resource 1).

\section{Araneae}

Four species of linyphiid spider were collected from the three locations on the west coast surveyed in 2009 (Online Resource 1); Erigone psychrophila Thorell, 1871 at one
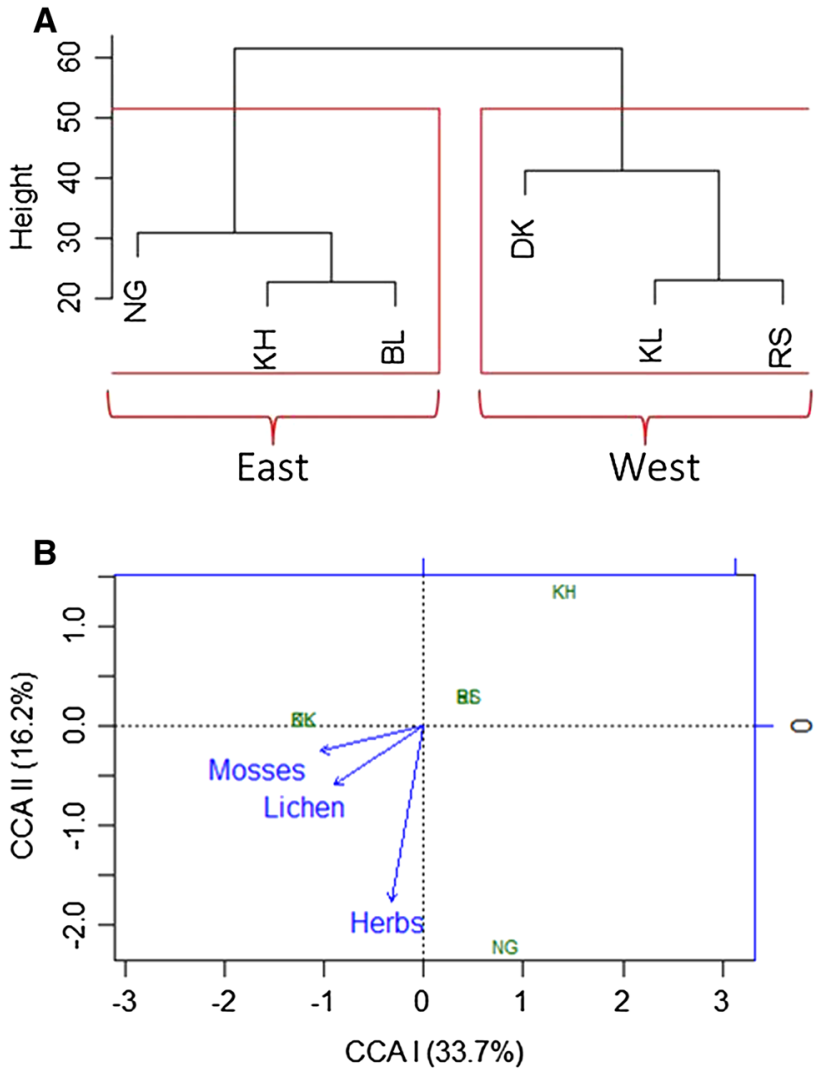

C
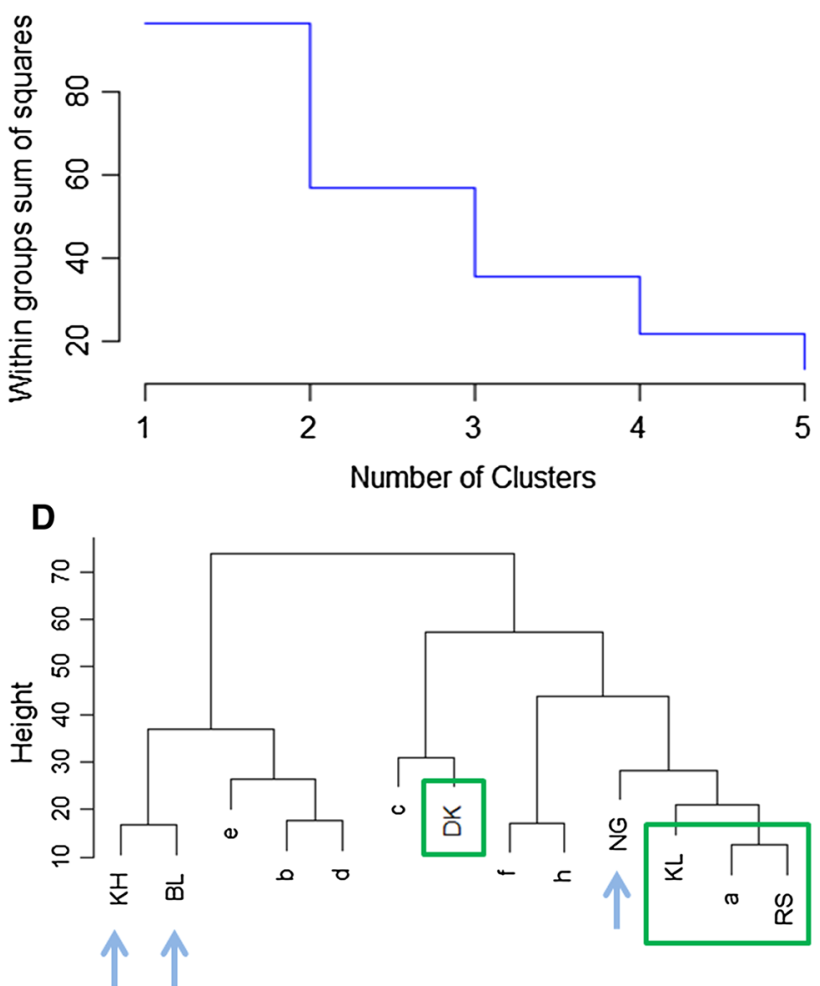

site (Diskobukta), E. arctica palearctica (White, 1852) two sites, Collinsia spetsbergensis (Thorell, 1871) two sites, and Hilaria glacialis (Thorell, 1871) from only Kapp Lee. 
Spiders were not, unfortunately, identified from the east coast site samples. None of the spiders were new species records for Svalbard.

\section{Collembola}

A total of 38 collembolan species occurred in samples taken in the 2009 and 2010 surveys; two of them were new records to Svalbard: Folsomia ciliata Babenko \& Bulavintsev, 1993 and Pseudanurophorus psammophilus (Potapov $\&$ Stebaeva, 2002) (both found only on the west coast of Edgeøya) (Table 2, Online Resource 1). The communities between the two coasts differed markedly. Of the 39 species identified in total, 38 were observed on the west coast while only 24 were sampled from the east coast sites. Only one species was restricted to one coast, Lepidocyrtus lignorum (Fabricius, 1775) observed at Negerdalen on the east coast. Seven species (18\%) were seen at all six sampling sites.

\section{Chironomidae (Diptera, Insecta)}

A total of ten species of Chironomidae were found in the samples belonging to four different genera, five of which were new records for Svalbard and four undescribed species (Table 2, Online Resource 1). These genera are all of the subfamily Orthocladiinae and are known to have terrestrial representatives. The immature stages of many terrestrial Chironomidae are poorly known and often have reduced morphological diagnostic features, which makes them difficult to discriminate. The chironomid larvae collected at Edgeøya were DNA barcoded and associated with identified adults from Svalbard and/or other Arctic regions, particularly northern Canada. The larvae are therefore identified to species-level even if not always linked to formally described species. Most species appear to be fairly widely distributed in the Arctic, except for Smittia sp. 1ES, which is so far only documented from Svalbard. The following taxa are recorded (provisional names with identifiers initials are used for taxa that could not be matched with formally described species): Allocladius sp. 1ES, Limnophyes pumilio (Holmgren, 1869), Metriocnemus brusti Sæther, 1989, Metriocnemus ursinus (Holmgren, 1869), Metriocnemus sp. 1ES, Smittia brevipennis (Boheman, 1856), Smittia extrema (Holmgren, 1869), Smittia sp. 1ES, Smittia sp. 6ES, Smittia sp. 28ES.

\section{Discussion}

This report comprises the most complete description of the invertebrate fauna of the eastern region of Svalbard to date. This examination is used to expand the understanding of the ecology of Svalbard but also to examine whether there are differences in the invertebrate distribution between the western and eastern regions of Svalbard and whether these differences can be partly, or wholly, explained by colonisation process subsequent to the retreat of the ice at the end of the last glacial maximum. Our results show that a relatively small-scale study, in this case at the scale of an island, is sufficient to infer larger biogeographical patterns, as the disparities between the east and the west communities observed here cannot be obviously explained by habitat differences alone.

Out of the 140 invertebrate species found in Edgeøya, $16(11 \%)$ were new records for Svalbard. Of the taxa that were sampled from both coasts, eight species of the new species for Svalbard occurred exclusively from the east coast of Edgeøya, one only from the west coast and four from both coasts; Online Resource 1). Those species have never been reported before from western locations in spite of the extensive literature amounting to over 650 articles (Coulson 2007; Coulson et al. 2014a).

\section{The invertebrate fauna of Edgeøya}

The 16 new species records come from a limited sampling effort indicating that the Svalbard invertebrate inventory is very far from being complete (Hodkinson 2013; Coulson et al. 2014a). The use of additional sampling methodologies such as pitfall traps, sticky traps or water traps for highly mobile and flying invertebrates, are needed to obtain a more complete picture on the invertebrate fauna of Edgeøya. In addition, the use of innovative DNA techniques (Ekrem et al. 2018; Søli et al. 2018) along with integrative approaches (Kaczmarek et al. 2018) and planned monitoring campaigns (Gillespie et al. 2018) are required to fully documented biodiversity in the Arctic.

Zero observations, that is the lack of a species observation despite surveying, is a problem that often bedevils biodiversity studies. To some extent this is also the case with this study. It is not possible to state conclusively that the species collected from Edgeøya, and that represent new species records for Svalbard, do not occur along in the western margins. However, there has been considerable sampling effort along the west coast, particularly around Isfjord (Longyearbyen and Barentsburg) and Kongsfjord (Ny-Ålesund). From these studies, projects and campaigns a large number of articles have arisen (Coulson et al. 2014a; Gillespie et al. 2016; Luoto et al. 2016; Kolicka 2017; Zawierucha et al. 2018). It is curious then that with limited sampling undertaken during this project that such a large percent of the species identified were new records if these species do indeed occur in habitats in the west of the archipelago. We conclude that the majority of these new species records represent species that have not yet expanded their ranges along the better-surveyed western regions. 
Rotifera A total of 68 bdelloid and 134 monogonont species have been reported from Svalbard (Kaya et al. 2010; Coulson et al. 2014a). The 27 bdelloids and 5 monogononts reported from this study from Edgeøya represent 40 and 4\%, respectively, of the known Svalbard diversity. This preponderance of bdelloids is in accordance with the few data on terrestrial mosses from Svalbard (Bryce 1897, 1966; Murray 1908; Summerhayes and Elton 1923; Kaya et al. 2010) and the general observation (e.g. Fontaneto and De Smet 2015) that monogononts are mostly present in truly aquatic habitats (i.e., water bodies), whereas bdelloids predominantly inhabit limno-terrestial habitats (i.e. mosses, lichens and soil). All the identified species have a wide-spread, or cosmopolitan, distribution with the exception of M. quadricornifera vanoye $i$ which is only known from the Belgian coastal dune area and Encentrum sp. nov. No sampling for rotifers was done at the west coast of Edgeøya during this study. However, the bdelloid species diversity from the Edgeøya east coast sites (27 species) was distinctly less than observed from the southern coastal region of Isfjorden (on the west coast of Spitsbergen) where Kaya et al. (2010) reported 68 species.

\section{Enchytraeidae}

Care must be taken in interpreting this species list. Potentially, these differences observed here could be due species specific tolerance to the stresses involved during transportation and the period before extraction. Nonetheless, of the 11 enchytraeid species found, three were new records to Svalbard. Cernosvitoviella cf. pusilla Nurminen, 1973 has a mainly Eastern Palaearctic distribution and has been described from springs in the South-East Alps (Stoch et al 2011). Mesenchytraeus melanocephalus has been described from Siberian Tundra (Christensen \& Dózsa- Farkas, 1999) and Alaska (Dózka-Farkas and Christensen 2002). The species Mesenchytraeus sp. is a species new for science to be described from Alaska and the location in Edgeøya (DózsaFarkas, unpublished). Marionina aporus Stephenson, 1925 has been described first from Spitsbergen (Stephenson 1925), later from Wrangel Island (Christensen and DózsaFarkas 1999) and now from Edgeøya.

\section{Mesostigmata}

Very conspicuous differences were observed between locations especially when comparing the western and eastern parts of the island. Neoseiulus ellesmerei (Chant \& Hansell, 1971) has been previously recorded from the Northern Canada (Kolodochka and Gwiazdowicz 2014). Three female $N$. ellesmerei occurred at Russebukta. Our samples also contained individuals belonging to the rare species Saprosecans baloghi Karg, 1964, a new record to Svalbard and otherwise only known from few locations in central Europe (Karg 1993).

All the mesostigmatic mites reported here have been previously described from other North Palearctic locations. Zercon solenites has been previously collected from Cassiope heaths and fell-fields in Greenland (Gwiazdowicz et al. 2011a). Zercon forsslundi is widely distributed and has been described from moss, humus and litter of coniferous forest in North of Europe and also in Latvia and Lithuania (ÁvilaJiménez et al. 2011). On the other hand, A. oudemansi is only known from the Svalbard archipelago (Coulson et al. 2014b; Teodorowicz et al. 2014). Several species present widespread distributions throughout the High Arctic for example A. haarlovi Lindquist, 1963, A. multidentatus and A. weberi, are found in the Svalbard archipelago and other Palaearctic and Nearctic locations including Northern Canada and Northern Russia (Ávila-Jiménez et al. 2011; Gwiazdowicz et al. 2011a, b) while A. tschernovi is only previously known from cold High Arctic locations with sparse vegetation cover, such as Nordaustlandet (north Svalbard) (Coulson et al. 2011).

Two female Dermanyssus hirundinis (Hermann, 1804) were found in Blåbukta. This is mainly a parasitic species particularly found in birds nests on Spitsbergen and previously identified as free-living facultative parasite (Gwiazdowicz et al. 2012; Böcher 2015).

\section{Oribatida}

Most of the oribatids are cosmopolitan with only a few Arctic species (Svalbardia paludicola Thor, 1930, Ceratozetes spitsbergensis Thor, 1934 and Oribatella artica Thor, 1930) and Arctic/Alpine species (Camisia foveolata Hammer, 1955, Mycobates sarekensis (Trägårdh, 1910) and Diapterobates notatus (Thorell, 1871).

\section{Araneae}

A total 14 species of linyphiid spider are recorded from Svalbard (Dahl et al. 2018). The Edgeøya samples included only four species of the group. Despite that the Linyphidae are considered to be a generalist Arctic family, Dahl et al. (2018) showed that spider communities in Svalbard are patchy and vary greatly over both short landscape scales and season. The reduced diversity indicated from our sampling may be due to this patchy pattern and lack of comprehensive habitat sampling, season effects, or a genuine reduced spider biodiversity on Edgeøya. Erigone psychrophila Thorell, 1871 was observed at only one site (Diskobukta) although this species is reported as common at other regions in the Arctic, for example at Zackenberg on the east coast of Greenland where it was the most numerous spider collected (Høye and Forchhammer 2008) and as widespread on the west coast of 
Spitsbergen (Holm 1958). Nonetheless, it formed less than $1 \%$ of the almost 3,000 individuals collected by Dahl et al. (2018) from a wide range of habitat types on the west coast.

\section{Collembola}

Svalbard Collembola are relatively well known (Coulson et al. 2014a) with a total of 70 species recorded from the archipelago so far. Hence, the 40 collembolan species found on Edgeøya represent $57 \%$ of the known Svalbard diversity. The first of the two new species not previously described from Svalbard; $F$. ciliata is also known from central parts of the northern Palaearctic region including Novaya Zemlya and the Pechora River basin (Babenko et al. 2017) while the second, P. psammophilus was originally described from southern Siberia and still only known from the type locality in Asia (A Babenko pers comm.) and from a seashore meadow in Skjærvøy, northern Norway but believed to present a Palaearctic distribution.

\section{Diptera}

It is likely that there are a substantial number of chironomid species present on Edgeøya in addition to the ten species recorded here. The family Chironomidae is a frequent and species-rich group in freshwater habitats all over the Arctic. The family is the most species rich insect group in Svalbard with more than 70 recorded species (Ávila-Jiménez et al. 2011; Eidesen et al. 2013). Other Diptera families are likely also represented, including the Sciaridae that have soil-dwelling larvae. Other sampling strategies such as emergence traps, Malaise traps, netting, or floatation techniques probably would be more effective in catching a wider representation of Diptera.

\section{Tardigrada}

In addition to the previously described taxa, Zawierucha et al. (2013) examined the Tardigrada at the same sites as in this study and it is appropriate to comment on the results here. Thirteen species were identified in the study of which nine were only recovered from the east coast sites, two from the west coast and two were present on both coasts. Hence, within the restrictions of the study discussed previously, there is a clear distinction in the Tardigrada communities between the east and west coasts.

\section{Biodiversity and dispersal in the Arctic}

Stochastic processes linked to dispersal and establishment could be expected to show a west-to-east bias as a consequence of the influence of two clearly delimited dispersal routes (including the Siberian transpolar route and winds associated, and the north Atlantic influence in the west coast; Fig. 1, Ávila-Jiménez and Coulson 2011). Using chironomid barcodes from across the northern Atlantic, Ekrem et al. (2018) observed that the Greenland fauna has affinities to both the western Palaearctic and the northern Nearctic. Moreover, that the eastern connexion to the Palaearctic is stronger than previously believed and speculate that this connexion may be the result of polar easterlies and the ability of chironomids to disperse as aerial plankton (Ekrem et al. 2018). A community analysis of the invertebrates sampled reveals a clear east/west difference in species distribution (Fig. 5a) which to a large extent cannot be explained by habitat differences. These differences seem to be more obvious in groups such as mesostigmatid mites where the new species described had either a general Nearctic distribution (for those found in the west coast of Edgeøya) or eastern Palearctic distribution (for those found in eastern locations) supporting the hypothesis of an east/west bias. All the Collembola found in Edgeøya as new records for Svalbard are generally found in the eastern Palaearctic and are probably absent or rare from other Arctic areas. In fact, when collembolan assemblages from different locations from Edgeøya are analysed in the context of their distribution throughout High Arctic islands two locations, Kapp Lee (KL) and Russebukta (RS), cluster together with "Svalbard" assemblages, whilst the communities found in the other Edgeøya locations show distribution patterns similar to those of species found in the eastern High Arctic islands north of Siberia (Fig. 5d). This pattern is also seen in the enchytraeids where two out of the three species new to Svalbard described from Edgeøya show mainly eastern Palaearctic/Beringian distributions. By contrast, the highly stress-resistant rotifers are mainly cosmopolitan species. The effect of nutrient input from birdcliffs has been demonstrated to effect the invertebrate fauna (Zmudczyńska et al. 2012; Zmudczyńska-Skarbek et al. 2015). However, in this study, none of the sampling localities lie in close proximity to birdcliffs and habitat variables cannot explain up to $35.5 \%$ of the differences among sites. Thus, whilst habitat type is shown to be essential to define soil invertebrate assemblages, these results highlight the need to correct, or allow for, for dispersal patterns and other historical factors shaping species distribution, even when studying ecological patterns at relatively short scales.

In conclusion, comprehensive community descriptions are essential to understand the mechanisms underlying the origin of biodiversity and species distribution to predict potential ecological shifts. This is specially valid for rapidly changing Arctic environments such as the Svalbard archipelago where mean annual air temperature has risen from $-9{ }^{\circ} \mathrm{C}$ in 1910 to $-3.5^{\circ} \mathrm{C}$ in 2010 (Førland et al. 2011).

Neutral and niche theory has fuelled heated arguments amongst ecologists for perhaps too long. Whilst both theories are accepted by many in a synergistic consensus, the 
debate continues on whether it is one factor (dispersal), or the other (habitat), that is the main driving force behind biological diversity. In this High Arctic, scenario neither niche theory nor neutral theory appeared to be strong enough on their own to explain invertebrate distribution. While habitat is certainly an important determinant of species distribution, our results support for the prominence of dispersal even at such relatively short scales as a factor which should, at least, not be ignored.

Acknowledgements This article is dedicated to T. Solhøy who passed away at a late stage in the preparation of the manuscript. Henrik Nygård assisted in sample collection 2010. The project received financial support from the Svalbard Arctic Field Grant and the Svalbard Environmental Protection Fund. Our thanks are also extended to Airlift AS and their aircrew for providing helicopter transport. DNA barcode data in this publication was generated in collaboration with the Norwegian Barcode of Life Network (NorBOL) funded by the Research Council of Norway and the Norwegian Biodiversity Information Centre. We would finally like to thank the three reviewers (Dr. I.C. Barrio, Prof. A. Babenko and one anonymous) for their highly constructive comments that greatly improved the manuscript.

\section{Compliance with ethical standards}

Conflict of interest There are no known conflicts of interest and all fieldwork was undertaken after obtaining appropriate permission from the Governor of Svalbard (2008/00925-7 a.512 and 2008/00925-5 a.512)

Open Access This article is distributed under the terms of the Creative Commons Attribution 4.0 International License (http://creativeco mmons.org/licenses/by/4.0/), which permits unrestricted use, distribution, and reproduction in any medium, provided you give appropriate credit to the original author(s) and the source, provide a link to the Creative Commons license, and indicate if changes were made.

\section{References}

Alsos IG, Eidesen PB, Ehrich D, Skrede I, Westergaard K, Jacobsen GH, Landvik JY, Taberlet P, Brochmann C (2007) Frequent long- distance plant colonization in the changing Arctic. Science 316:1601-1608

Ávila-Jiménez ML (2011) Coulson SJ (2011) Can snow depth be used to predict the distribution of the high Arctic aphid Acyrthosiphon svalbardicum (Hemiptera: Aphididae) on Spitsbergen? BMC Ecol $11: 25$

Ávila-Jiménez ML, Gwiazdowicz DJ, Coulson SJ (2011) The mesostigmatid mite (Acari: Parasitiformes) fauna of Svalbard: a revised inventory of a high Arctic archipelago. Zootaxa 3091:33-41

Babenko A, Potapov MB, Taskaeva AA (2017) The collembolan fauna of the east European tundra. Russ Entomol 26:1-30

Babenko A, Fjellberg A (2006) Collembola Septentrionale. KMK Scientific Press Ltd, Moscow

Beyens L, Chardez D, De Bock P (1986) Some new and rare Testate Amoebae from the Arctic. Acta Protozool. 25:81-91

Beyens L, De Bock P (1989) Moss dwelling diatom assemblages from Edgeøya. Polar Biol 9:423-430

Boheman CH (1865) Bidrag til kännendom om Spetsbergens insektfauna. Ofv. K Svenska Vet-Akad Forh B 22:563-577
Brochmann C, Gabrielsen TM, Nordal I, Landvik JY, Elven R (2003) Glacial survival or tabula rasa? The history of the North Atlantic biota revisited. Taxon 52:417-450

Bryce D (1897) Contributions to the non-marine fauna of Spitsbergen.Part II. Report on the Rotifera. Proc Zool Soc London 52:793-799

Bryce D (1922) On some Rotifera from Spitsbergen. The Oxford University Expedition to Spitsbergen, 1921. J Quekett Microsc Cl, Ser. 2, 14(88):305-332

Böcher J (2015) Greenland Entomofauna. An identification manual of insects, spiders and their allies. Fauna Entomol Scand 44. Brill, Leiden

Christensen B (1999) Enchytraeid fauna of the Palearctic tundra (Oligochaeta, Enchytraeidae). Kong Danske Videnskabs Selskab Biologiske Skrifter 52

Christensen B, Dózsa-Farkas K (1999) The enchytraeid fauna of the Palearctic tundra (Oligochaeta, Enchytraeidae). Biologiske Skrifter Dan Vid Selsk 52:1-37

Convey P, Abbandonato HDA, Bergan F, Beumer LT, Biersma EM, Bråthen VS, D'Imperio L, Jensen CK, Nilsen S, Paquin K, Stenkewitz U, Svoen ME, Winkler J, Müller E, Coulson SJ (2015) Survival of rapidly fluctuating natural low winter temperatures by Arctic soil invertebrates. J Therm Biol 54:111-117

Convey P, Coulson SJ, Worland MR, Sjöblom A (2018) Implications of annual and shorter term temperature patterns and variation in the surface levels of polar soils for terrestrial biota. Polar Biol 41:1587-1605

Coulson SJ (2007) The terrestrial and freshwater invertebrate fauna of the High Arctic archipelago of Svalbard. Zootaxa 1448:41-58

Coulson SJ, Refseth D (2004) The terrestrial and freshwater invertebrate fauna of Svalbard (and Jan Mayen) in Prestrud P, Strøm H, Goldman H (eds) A catalogue of the terrestrial and marine animals of Svalbard. Skrifter 201. Norwegian Polar Institute, Troms $\varnothing$ pp 57-122

Coulson SJ, Fjellberg A, Snazell R, Gwiazdowicz DJ, Ávila Jiménez ML (2011) On the Collembola, Araneae and Gamasida from the Kinnvika region of Nordaustlandet, Svalbard. Geogr Ann A 93:253-257

Coulson SJ, Convey P, Aakra K, Aarvik L, Ávila-Jiménez ML, Babenko A, Biersma E, Boström S, Brittain J, Carlsson A, Christoffersen KS, De Smet WH, Ekrem T, Fjellberg A, Füreder L, Gustafsson D, Gwiazdowicz DJ, Hansen LO, Holmstrup M, Hullé M, Kaczmarek Ł, Kolicka M, Kuklin V, Lakka H-K, Lebedeva N, Makarova O, Maraldo K, Melekhina E, Ødegaard F, Pilskog HE, Simon JC, Sohlenius B, Solhøy T, Søli G, Stur E, Tanasevitch A, Taskaeva A, Velle G, Zawierucha $\mathrm{K}$, Zmudczyńska $\mathrm{K}$ (2014a) The terrestrial and freshwater invertebrate biodiversity of the archipelagoes of the Barents Sea: Svalbard, Franz Josef Land and Novaya Zemlya. Soil Biol Biochem 68:440-470

Coulson SJ, Schatz H, Gwiazdowicz DJ, Solhøy T (2014b) The oribatid and mesostigmatid mite fauna (Acari) of the High Arctic island of Hopen. Pol Polar Res 35:133-213

Dahl MT, Yoccuz NG, Aakra K, Coulson SJ (2018) The Araneae of Svalbard: landscape scale spider community diversity in the High Arctic. Polar Biol 41:839-853

De Smet WH (1998) Preparation of rotifer trophi for light and scanning electron microscopy. Hydrobiologia 387(388):117-121

De Smet WH, Pourriot R (1997) Rotifera. Vol. 5. The Dicranophoridae and the Ituridae (Monogononta). In: T Nogrady (ed). Guides to the Identification of the Microinvertebrates of the Continental Waters of the World, vol. 12. SPB Academic Publishing bv. The Hague

Donner, J (1965) Ordnung Bdelloidea (Rotatoria, Rädertiere). Bestimmungsbücher zur Bodenfauna Europas. Vol. 6. Akademie Verlag, Berlin

Eidesen PB, Dorothee Ehrich D, Bakkestuen V, Alsos IG, Gilg O, Taberlet P, Brochmann C (2013) Genetic roadmap of the Arctic: 
plant dispersal highways, traffic barriers and capitals of diversity. New Phytol 200:898-910

Ekrem T, Stur E, Orton MG, Adamowicz SJ (2018) DNA barcode data reveal biogeographic trends in Arctic non-biting midges. Genome 61:787-796

Ferrington L, Sæther OA (2011) A revision of the genera Pseudosmittia Edwards, 1932, Allocladius Kieffer, 1913, and Hydrosmittia gen. n. (Diptera: Chironomidae, Orthocladiinae). Zootaxa 2849:1-314

Fjellberg A (1998) The Collembola of Fennoscandia and Denmark. Part I: Poduromorpha. Fauna Entomologica Scandinavica 35. Brill, Leiden

Fjellberg A (2007) The Collembola of Fennoscandia and Denmark. Part II: Entomobryomorpha and Symphypleona. Fauna Entomologica Scandinavica 42. Brill, Leiden

Folmer O, Black M, Hoeh W, Lutz R, Vrijenhoek R (1994) DNA primers for amplification of mitochondrial cytochrome c oxidase subunit I diverse metazoan invertebrates. Mol Marine Biol Biotech 3:294-299

Fontaneto D, De Smet WH (2015) Rotifera. In: Schmidt-Rhaesa A (ed) Handbook of Zoology: Gastrotricha, Cycloneuralia and Gnathifera. Gastrotricha and Gnathifera De Gruyter, Berlin, pp 217-300

Førland EJ, Benestad R, Hanssen-Bauer I, Haugen JE, Skaugen TE (2011) Temperature and precipitation development at Svalbard 1900-2100. Adv. Meteorol, Article ID, p 893790

Gillespie MAK, Baggesen N, Cooper EJ (2016) High Arctic flowering phenology and plant-pollinator interactions in response to delayed snow melt and simulated warming. Environ Res Lett 11:115006

Gillespie MAK, Alfredsson M, Barrio IC, Bowden JJ, Convey P, Culler LE, Coulson SJ, Krogh PH, Koltz AM, Koponen S, Loboda S, Marusik Y, Sandström JP, Sikes DS, Høye TT (2018) Status and trends of terrestrial arthropod abundance and diversity in the North Atlantic region of the Arctic. Ambio. https://doi. org/10.1007/s13280-019-01162-5

Gwiazdowicz DJ, Teodorowicz E, Coulson SJ (2011a) Redescription of Zercon solenites Haarløv, 1942 (Acari: Mesostigmata: Zerconidae) with a key to the Svalbard Species of the Genus Zercon. Int J Acarol 37:135-148

Gwiazdowicz DJ, Teodorowicz E, Coulson SJ (2011b) Redescription of Arctoseius haarlovi Lindquist, 1963 (Acari: Ascidae) from Spitsbergen, Svalbard. Entomol Fenn 22:140-1481

Gwiazdowicz DJ, Coulson SJ, Grytnes JA, Pilskog HE (2012) The bird ectoparasite Dermanyssus hirundinis (Acari, Mesostigmata) in the High Arctic; a new parasitic mite to Spitsbergen, Svalbard. Acta Parasitol 57:378-384

Haugan PM (1999) Structure and heat content of the West Spitsbergen Current. Polar Res. 18:183-188

Hernández-Triana LM, Prosser SW, Rodríguez-Perez MA, Chaverri LG, Hebert PDN, Ryan Gregory T (2014) Recovery of DNA barcodes from blackfly museum specimens (Diptera: Simuliidae) using primer sets that target a variety of sequence lengths. Mol Ecol Resour 14:508-518

Hodkinson ID (2013) Terrestrial and freshwater invertebrates. In: Meltofte $\mathrm{H}$ (ed) Arctic Biodiversity Assessment. Status and Trends in Arctic biodiversity, Conservation of Arctic Flora and Fauna, CAFF, Akureyri, pp 194-223

Holmgren AE (1869) Bidrag till kannedomen om Beeren Eilands och Spetsbergens insekt fauna. K. Svenska Vet. Akad. Handl. 8:1-56

Ingólfsson Ó, Landvik JY (2013) The Svalbard-Barents Sea ice-sheetHistorical, current and future perspectives. Quaternary Sci Rev 64:33-60

Ivanova NV, DeWaard JR, Hebert PD (2006) An inexpensive, automation-friendly protocol for recovering high-quality DNA. Mol Ecol Notes 6:998-1002

Jersabek CD, De Smet WH, Hinz C, Fontaneto D, Hussey CG, Michaloudi E, Wallace RL, Segers H (2015) List of Available Names in Zoology, Candidate Part Phylum Rotifera, species-group names established before 1 January 2000. Final version,11 April 2018. https://www.rotifera.hausdernatur.at/. Accessed 11 Apr 2018

Johansen S (1999) Origin of driftwood in north Norway and its relevance for transport routes of drift ice and pollution to the Barents Sea. Sci Total Environ 231:201-225

Kaczmarek Ł, Zawierucha K, Buda J, Stec M, Gawlak M, Michalcyk Ł, Roszkowska M (2018) An integrative redescription of the nominal taxon for the Mesobiotus harmsworthi group (Tardigrada: Macrobiotidae) leads to descriptions of two new Mesobiotus species from Arctic. PLoS ONE 13(10):e0204756

Karg W (1993) Acari (Acarina), Milben Parasitiformes (Anactinochaeta), Cohors Gamasina Leach. Raubmilben. Die Tierwelt Deutschlands, 59 Teil. Gustav Fischer Verlag, Jena, p 523

Kaya M, De Smet WH, Fontaneto D (2010) Survey of moss-dwelling bdelloid rotifers from middle Arctic Spitbergen (Svalbard). Polar Biol 33:833-842

Keith SA, Webb TJ, Böhning-Gaese K, Connolly SR, Dulvy NK, Eigenbrod F, Jones KE, Price T, Redding DW, Owens IPF, Isaac NJB (2012) What is macroecology? Biol Lett 8:904-906

Kolicka M (2017) New Arctic Gastrotricha-three Chaetonotus (Chaetonidae) from Longyearbyen Svalbard (Spitsbergen, Svalbard Archipelago). Ann Zool 67:131-180

Kolodochka LA, Gwiazdowicz DJ (2014) A new species of predaceous mite of the genus Neoseiulus Hughes (Acari, Phytoseiidae), with redescriptions of $N$. magnanalis (Thor) and $N$. ellesmerei (Chant \& Hansell), from Svalbard. High Arctic. Zootaxa 3793:441-452

Koste W (1978) Rotatoria. Die Rädertiere Mitteleuropas. Ein Bestimmungswerk, begründet von Max Voigt. Überordnung Monogononta, vol. 2. Borntraeger, Berlin

Kutikova LA (2005) The bdelloid rotifers of the fauna of Russia. KMK Scientific Press Ltd, Moscow

Landvik JY, Bondevik S, Elverh øl A, Fjeldskaar W, Mangerund JAN, Salvigsen O, Siegert MJ, Svendsen JI, Vorren TO (1998) The last glacial maximum of Svalbard and the Barents sea area: ice shee extent and configuration. Quaternay Sci Rev 17:43-75

Luoto TP, Oksman M, Ojala AEK (2016) Invertebrate communities of High Arctic ponds in Hornsund. Pol Polar Res 37:105-119

Murray J (1908) Arctic rotifers collected by Dr William S. Bruce. Proc Roy Phys Soc Edinburgh 17:121-127

Maucci W (1996) Tardigrada of the Arctic tundra with descriptions of two new species. Zool J Linn Soc 116:185-204

Norwegian Polar Institute (2003) Placenames of Svalbard Rapportserie 122. NPI, Tromsö

Norton R, Behan-Pelletier V (2009) Suborder Oribatida. In: Krantz GW, Walter DE (eds) A manual of acarology. Texas Tech University Press, Lubbock, pp 430-464

O'Connor FB (1962) The extraction of Enchytraeidae from soil. In: Murphy PW (ed) Progress in soil zoology. Butterworths Publishers, London, pp 279-285

Oksanen J, Kindt R, Legendre P, O'Hara B, Stevens MHH, Oksanen MJ (2007) Suggests MASS. Commun Ecol Package 10:631-637

Przybylak R, Araźny A, Nordli Ø, Finkelnburg R, Kejna M, Budzik T, Migała K, Sikora S, Puczko D, Rymer K, Rachlewicz G (2014) Spatial distribution of air temperature on Svalbard during 1 year with campaign measurements. Internat J Climatol 34:3702-3719

R Development Team (2014) R: a language and environment for statistical computing. R Foundation for Statistical Computing, Vienna, Austria

Sæther OA (1975) Twelve new species of Limnophyes Eaton, with keys to Nearctic males of the genus (Diptera: Chironomidae). Can Entomol 107:1029-1056

Sæther OA (1990) A review of the genus Limnophyes Eaton from the Holarctic and Afrotropical regions. Entomol Scand Suppl 35:1-135 
Sæther OA (1995) Metriocnemus van der Wulp: seven new species, revision of species, and new records (Diptera: Chironomidae). Interg J Limnol 31:35-64

Sæther OA (2004) The chironomids (Diptera, Chironomidae) described by Lundström (1915) from arctic Siberia, with a redescription of Derotanypus sibiricus (Kruglova \& Chernovskii). Zootaxa 595:1-35

Schatz H, Behan-Pelletier VM (1968) O'Connor BM \& Norton RA (2011) Suborder Oribatida van der Hammen. Zootaxa 3148:141-148

Schatz H, Fischer BM (2011) Hornmilben (Acari, Oribatida). In: Wilhalm T, Schatz H (eds) GEO-Tag der Artenvielfalt $2010 \mathrm{im}$ Pfelderer Tal (Passeier, Gemeinde Moos i.P., Südtirol, Italien). Gredleriana, vol 11, pp 189-194

Segers H (1995) Rotifera. Vol. 2. The Lecanidae (Monogononta). In: Nogrady T (ed.). Guides to the identification of the microinvertebrates of the continental waters of the world, vol. 6. SPB Academic Publishing bv, The Hague

Stephenson J (1925) The Oligochæta of Spitsbergen and Bear Island; Some Additions and a Summary. Proc Zool Soc Lond 95:1293-1322

Stoch F, Reinhard G, Pieri V, Rossetti G, Sambugar B (2011) Exploring species distribution of spring meiofauna (Annelida, Acari, Crustacea) in the south- eastern Alps. J Limnol 70:65-76

Stur E, Ekrem T (2011) Exploring unknown life stages of Arctic Tanytarsini (Diptera: Chironomidae) with DNA barcoding. Zootaxa 2743:27-39

Summerhayes VS, Elton CS (1923) Contributions to the ecology of Spitsbergen and Bear Island. J Ecol 11:214-286

Summerhayes VS, Elton CS (1928) Further contributions to the ecology of Spitsbergen. J Ecol 16:193-268

Søli G, Arvik L, Magnussen T (2018) Plutella polaris Zeller, 1880 (Lepidoptera Plutellidae) rediscovered at Svalbard, Norway, with comments on its taxonomic position. Noto Lepidopterol 41:129-137

Teodorowicz E, Gwiazdowicz DJ, Coulson SJ (2014) Redescription of Antennoseius (Vitzthumia) oudemansi (Acari, Mesostigmata) from Spitsbergen, Svalbard. Entomol Fenn 25:27-42

Thompson R, Townsend C (2006) A truce with neutral theory: local deterministic factors, species traits and dispersal limitation together determine patterns of diversity in stream invertebrates. $\mathrm{J}$ Anim Ecol 75:476-484

Venables WN, Ripley BD (2013) Modern applied statistics with S-PLUS. Springer, New York

Westergaard KB, Alsos IG, Popp M, Edgelskjøn T, Flatberg KI, Brochmann C (2011) Glacial survival may matter after all: nunatak signatures in the rare European populations of two west-arctic species. Mol Ecol 20:376-393

Zawierucha K, Coulson J, Michalczyk $Ł$, Kaczmarek Ł (2013) Current knowledge on the Tardigrada of Svalbard with the first records of water bears from Nordaustlandet (High Arctic). Polar Res 32:20886. https://doi.org/10.3402/polar.v32i0.20886

Zawierucha K, Podkowa P, Marciniak M, Gąsiorek P, Janko K, Zmudcyńska-Skarbek K, Włodarska-Kowalczuk M (2018) Temperature (latitude) and nutrient (seabird guano) effects on limnoterrestrial Tardigrada (Testechiniscus spitsbergensis and Pilatobius recamieri) body size. Pol Res 31:1492297

Zonneveld M, Lebouille de Nies N with the cooperation of van Dijk A, Heinemeijer H, Oosterveld P (2004) Landscape ecology ('land unit') map of Edgeøya, Spitsbergen with emphasis on vegetation. In: Boschman N, Hacquebord L (eds) Permanence in diversity: Netherlands Ecological Research on Edgeøya, Spitsbergen. Barkhuis Publishing, Groningen, pp 103-162

Zmudczyńska K, Olejniczak I, Zwolicki A, Iliszko L, Convey P, Stempniewicz L (2012) Influence of allochtonous nutrients delivered by colonial seabirds on soil collembolan communities on Spitsbergen. Polar Biol 35:1233-1245

Zmudczyńska-Skarbek K, Zwolicki A, Convey P, Barcikowski M, Stempniewicz L (2015) Is ornithogenic fertilisation important for collembolan communities in Arctic terrestrial ecosystems? Polar Res 34:25629. https://doi.org/10.3402/polar.v34.25629

Publisher's Note Springer Nature remains neutral with regard to jurisdictional claims in published maps and institutional affiliations. 